\title{
ALTERNATIVE METHODS FOR CONTROL OF THE LONG HORNED BORER Niphona picticornismuls. (COLEOPTERA: CERAMBYCIDAE) IN GRAPE ORCHARDS. Iman I. Imam Desert Research Center
}

\begin{abstract}
Trials were conducted in Nubaria district, Behaira Governorate, to evaluate the infestation reduction for the cerambycid borer Niphona picticornis, Muls. infesting grape trees during two successive years 2013 and 2014, dormant pruning alone resulted in $43.22 \%$ reduction of infestation during 2013 and increased to $54.04 \%$ in 2014, summer pruning resulted in $1.87 \%$ and $10 \%$ reduction during 2013 and 2014 respectively, while both dormant and pruning summer achieved $46.11 \%$ and $58.62 \%$ reduction of infestation during the two years of study, respectively. Mechanical treatment recorded $6.68 \%$ and $18.26 \%$ reduction, while, bioformulations treatments (bacteria and fungi formulations) achieved $3.32 \%, 6.20 \%$ and increased to $7.25 \%$, $10.92 \%$ in the two years of study respectively, on the other hand both local painting and local spray treatments using Basudin $60 \% \mathrm{EC}$ and Cidial $50 \% \mathrm{EC}$, resulted in $47.07 \%, 42.74 \%$ in 2013 and increased to $56.79 \%, 61.41 \%$ reduction of the borer infestation in 2014, finally, the combined treatments i.e., pruning, worming, local painting or local spraying achieved the highest reduction of the borer infestation, reached 81.56 and $79.72 \%$ respectively.
\end{abstract}

\section{INTRODUCTION}

The basic information in "Integrated Control Programs"are determination the economic importance of the target pest(s), the importance of the crop, and the seasonal fluctuation of these pests population. Accordingly, grapes are economically one of the profitable crops in Egypt. Grapes orchards are subject to serious woodborers such as the carpenter moth Paroptaparadoxa (Lepidoptera: Cossidae), Chlorophrusvarius (Coleoptera: Cerambycidae), Ptosimaundecimmaculata (Coleoptera: Buprestidae), Enneadesmusforficulaand Phonapatefrontalis (Coleoptera: Bostrichidae) Abd El-latif (1995) and Batt (2002).

(Willcocks, 1924) recorded $N$. picticornisbeetles on pomegranate, while Moussa (1977) added fig and casuarinas trees. Batt (1999) recorded $N$. picticornisbeetles infesting branches and twigs of grape living trees. He described symptoms of infestations and damage.

Haggag (2000) mentioned that $N$. picticornisis a harmful pest to mulberry trees in Egypt. He found that larvae attack the branches and twigs of trees to live and feed inside the wood causing their dryness and death. He added that the duration of generation was 320-340 days indicating that the insect might have one generation per year. $N$. picticorniswas recorded infesting standing mango trees by Hashim, 2009.

None of the previous work had trials for controlling $N$. picticornisinfesting grape trees, so, the aim of present work is to evaluate alternative and environmental safe treatments for their efficiency to check the 
ravages of this borer in grape orchards in order to maximize the role of the biological control agents in the environment, minimize the environmental pollution with insecticides, and preserve the human and animal health.

\section{MATERIALS AND METHODS}

Old grape orchards (more than 20 years), about 10 feddan area " feddan $=4.2$ hectare" with trees approximately $8 \times 8$ meters apart located at El Nubaria district, Behaira Governorate were subjected to control trials. Grape trees were severely infested with the cerambycid borer $N$. picticornisExperiments were extended during two successive seasons from January 2013 to December 2014.

The following 14 treatments were evaluated in the grave orchards using completely randomized design (10 infested trees for each treatment and each tree was considered a replicate).

A. Horticultural treatments:

1. Dormant pruning treatment:

In winter (January 2013), the regular horticultural winter pruning was conducted including the dead and infested branches and stubs (characterized with exit holes of $N$. picticornisborer)using a sharp pruning soccer and a saw.

\section{Summer pruning treatment:}

During late June, branches showed new infestation were pruned.

3. Dormant and summer pruning treatments:

Treatments numbers 1 and 2 were applied together.

\section{B. Effect of mechanical treatment:}

1. Worming treatment:

After pruning, a knife and a flexible wire were used to scratch the infested areas on the stem and branches to kill as possible the larvae and sometimes dwelling pupae and / or adults.

\section{Microbiological treatments:}

1. Bacterial treatment:

Bactospeine F.C. (a.i. Bacillus thuringiensis, Berliner, 8500 International Units $\mathrm{Ak} / \mathrm{mg}$ ) at the rate of $200 \mathrm{cc}$ per 100 liters of water was locally sprayed on the stem, main branches and pruning sites four times each season. Spraying was conducted by a small knapsack sprayer at monthly intervals on May, June, July and August.

\section{Fungal treatment:}

Biofly F.C. (a.i., Beauveria bassiana, $3 \times 10^{7}$ spores $/ \mathrm{mg}$ ) at the rate of 400 cc per 100 liters of water were locally sprayed on the stem, main branches and pruning sites four times each season. Spraying was carried out by a small knapsack sprayer at monthly intervals on May, June, July and August.

D. Chemical treatments:

\section{Local painting treatment:}

Stemex insecticide ( $3 \%$ Anthracine $+18 \%$ Naphthalene) was used to paint the stem, main branches and infested sites four times each season at monthly intervals (May, June, July, and August). Painting was practically using a brush. 


\section{Local spraying treatment:}

Basudin $60 \%$ EC and Cidial L 50\% EC each at the rate of $300 \mathrm{cc}$ per 100 liters of water was sprayed alternatively four times each season at monthly intervals (May, June, July, and August). Spraying was practiced by a knapsack sprayer and mainly directed towards the stem, branches as well as the other infested sites.

3. Complete coverage spray.

E. Combined treatments:

1. Pruning, worming, and bacterial treatment:

Treatment numbers 3,4 , and 5 were conducted together.

2. Pruning, worming, and fungal treatments:

Treatments numbers 3,4 , and 6 were conducted together.

3. Pruning, worming, and local painting treatments:

Treatments numbers 3,4 , and 7 were conducted together.

4. Pruning, worming, and local spraying treatments:

f. Untreated:

Treatments numbers 3,4 , and 8 were carried out together.

\section{Check treatment:}

Check trees were left untreated as control treatment.

\section{g. Procedures of treatments:}

The previously mentioned 13 treatments were carried out for the first season from January 2013 to December 2014. During the second season (January 2013 to December 2014), the same previous treatments were repeated on other infested trees in nearby area of the same orchard with the same technique for confirmation.

In the meantime, the same previous 13 treatments were conducted on the same first year trees to evaluate the effect of the same 13 treatments when applied for two successive years (from January 2013 to December 2014).

During the first week of January 2013, the old exit holes on the trees were canceled by paint. Treatments were evaluated by counting the newly emerged beetles indicated by the newly exit holes on the trees.New exit holes were counted by painting after each year treatment.

\section{h. Evaluation of treatments:}

The efficiency of treatments was based on the percentage reduction of the borer infestation, as follow:

Where,

$$
\% \text { reduction of infestation }=[(C-T) / C] 100
$$

C: the mean number of new exit holes in untreated trees.

$\mathrm{T}$ : the mean number of new exit holes in treated trees.

Grouping of treatments was based on ANOVA test and "Least Significant Difference" (Snedecor and Cochran, 1990). 


\section{RESULTS AND DISCUSSION}

A. Effect of one single year treatments (Direct effect):

a. Effect of horticultural treatments alone:

1. Effect of dormant pruning treatment:

As shown in Table (1) dormant pruning alone reduced $N$. picticornis infestation with 45.54 - $40.29 \%$ (mean, $43.22 \%$ ) each year. This low percentage reduction of infestation was due to the mode of larval infestation. Larvae existed mostly deep inside the stem and main branches which mostly did not included in the regular horticultural dormant pruning. However, pruning dying branches somewhat reduced the borer infestation.

2. Effect of summer pruning treatment:

Summer pruning was least effective as the degree of borer reduction of infestation resulted in $1.58-2.25 \%$ with a mean of $1.87 \%$ (Table, 1). Summer pruning was directed only towards the new shoots, some older sites and scarcely towards the fallen main branches due to relatively heavy fruiting coincided with heavy infestation.

3. Effect of dormant and summer pruning treatments:

Table (1) showed that when dormant and summer pruning were applied together resulted in slightly higher degree of $N$. picticornis reduction of infestation than dormant pruning alone (range, $43.56-48.13 \%$ and mean, $46.11 \%)$. This multiple effect was logically better than applying each treatment alone.

b. Effect of mechanical treatment alone:

4. Effect of worming treatment:

A noticeable reduction of $N$. picticornis infestation recorded when worming treatment was applied (range, $6.75-8.50 \%$ and mean, $6.68 \%$ ), (Table, 1). This was due to the compactness of the coarse sawdust resulted from the larval feeding and the existence of larger larval, pre-pupae and pupae stages close to the larval tunnel's openings.

c. Effect of microbiological treatments:

5. Effect of bacterial treatment:

Bacterial treatment was relatively ineffective in the field as the bacteria highly affected with the weather factors thus; these bacteria were difficult to reach the larval inside their tunnels. Table (1) emphasized these results as the percentage reduction in $N$. picticornis infestation ranged from $2.44-4.42$ $\%$, with a mean of $3.32 \%$ ).

6. Effect of fungal treatment:

As in bacterial treatment, the percentage reduction in $N$. picticornis infestation due to fungal treatment was as low as $5.02-7.60 \%$, with a mean of $6.20 \%$.

d. Effect of local treatments:

7. Effect of local painting treatment:

Local painting four times a year with "Stemex" insecticide on the stem and larger pruned areas increased the percentage reduction of $N$. picticornis infestation showing $41.38-51.58 \%$, with a mean of $47.07 \%$ (Table, 1). This high percent reduction is due to the unsuccessful trails of the borer to infest these sites. 


\section{Effect of local spraying treatment:}

As in local painting, local spraying four times a year with Basudin $60 \%$ EC and Cidial L 50\% EC alternatively to the stem, bases of main branches and pruned stubs adequately reduced $N$. picticornis infestation with 47.27 $37.03 \%$, with a mean of $42.74 \%$ (Table, 1$)$. This treatment hindered the beetle settings, the beetle oviposition, hatching and larval entry inside the grape wood.

Table 1: Effect of one single year treatments on the percentage reduction in $\mathbf{N}$. picticornis infestation in grape orchards at Nubaria district, Behaira Governorate during 2013 and 2014seasons.

\begin{tabular}{|c|c|c|c|c|c|c|}
\hline \multirow{3}{*}{ Treatments } & \multicolumn{6}{|c|}{$\%$ reduction of infestation } \\
\hline & \multicolumn{2}{|c|}{$\begin{array}{c}1^{\text {st }} \text { year } \\
2013\end{array}$} & \multicolumn{2}{|c|}{$\begin{array}{c}2^{\text {nd }} \text { year } \\
2014\end{array}$} & \multicolumn{2}{|c|}{ Mean } \\
\hline & $\begin{array}{l}\text { No. of } \\
\text { holes }\end{array}$ & $\%$ & $\begin{array}{l}\text { No. of } \\
\text { holes }\end{array}$ & $\%$ & $\begin{array}{l}\text { No. of } \\
\text { holes }\end{array}$ & $\%$ \\
\hline A: Horticultural Treatments: & & & & & & \\
\hline Dormant pruning & 5.1 & 45.54 & 4.3 & 40.29 & 4.70 & 43.22 \\
\hline Summer pruning & 10.2 & 1.58 & 7.8 & 2.25 & 9.10 & 1.87 \\
\hline Dormant \& summer pruning & 4.8 & 48.13 & 4.0 & 43.56 & 4.40 & 46.11 \\
\hline B: Mechanical Treatments: & & & & & & \\
\hline Worming & 9.6 & 6.75 & 7.4 & 6.60 & 8.50 & 6.68 \\
\hline C: Microbiological Treatments: & & & & & & \\
\hline Bacterial & 10.1 & 2.44 & 7.6 & 4.42 & 8.84 & 3.32 \\
\hline Fungal & 9.8 & 5.02 & 7.3 & 7.60 & 8.64 & 6.20 \\
\hline D: Local Chemical Treatments: & & & & & & \\
\hline Local painting & 4.4 & 51.58 & 4.2 & 41.38 & 4.39 & 47.07 \\
\hline Local spraying & 5.0 & 47.27 & 4.6 & 37.03 & 4.84 & 42.74 \\
\hline E: Combined Treatments: & & & & & & \\
\hline Treatments, $3+4+5$ & 4.9 & 0.9 & 3.7 & 46.82 & 3.94 & 51.39 \\
\hline Treatments, $3+4+6$ & 3.8 & 56.75 & 3.5 & 49.00 & 3.74 & 53.32 \\
\hline Treatments, $3+4+7$ & 1.5 & 76.58 & 1.4 & 71.83 & 1.54 & 74.47 \\
\hline Treatments, $3+4+8$ & 1.7 & 74.81 & 1.6 & 69.64 & 1.74 & 72.0 \\
\hline F: Untreated Treatments: & 105 & -- & 81 & -- & 930 & -- \\
\hline Check & 10.5 & -- & 8.1 & -- & 9.30 & -- \\
\hline
\end{tabular}

e. Effect of combined treatments:

9. Effect of pruning, worming and bacterial treatments:

The obtained result in Table (1) indicated that applying dormant pruning in winter with the summer pruning, worming treatment and bacterial treatment resulted in slightly higher percentage reduction in $N$. picticornis infestation due to their combined effect. These percentages reached only $0.9-46.8 \%$, with a mean of $51.39 \%$. Data showed that bacterial treatment did not increase the effectiveness of the combined treatments. The major percentage reduction was mainly due to pruning and slightly due to worming treatments.

10. Effect of pruning, worming and fungal treatments:

In addition, the effectiveness of these three treatments was mainly due to pruning and slightly due to worming but the fungal treatment did not add noticeable effect. This combined treatments resulted in $56.75-49.00 \%$, with a mean $53.32 \%$ (Table, 1 ). 


\section{Effect of pruning, worming and local painting treatments:}

Quite adequate reductions in $N$. picticornis infestation was achieved when dormant and summer pruning, worming and local painting treatments were applied together in grape orchards. Table (1) clarified that the percentage reductions in the borer infestation reached $76.58-71.83 \%$, with a mean of $74.47 \%$. These combined treatments were satisfactory in case of N. picticornis infestation.

12. Effect of pruning, worming and local spraying treatments:

Also, applying the three treatments altogether (dormant, summer pruning, worming and local spraying treatments) in grape orchards showed almost equal results to the previous treatments. The data in Table (1) concluded that these treatments reduced $N$. picticornis infestation with 74.81 $-69.64 \%$ (mean, $72.0 \%$ ). These combined treatments were of good value in case of $N$. picticornis infestation.

\section{B. Effect of two successive year treatments (Cumulative effect):}

a. Effect of horticultural treatments alone (pruning):

Dormant pruning treatment alone in winter slightly reduced $N$. picticornis infestation in spite of repeating this treatment for two successive years (Table, 2). This low percentage reduction of infestation $(54.04 \%)$ was because the concentration of larval infestation in the stem and main branches. However, winter pruning treatment somewhat share in reduced the borer infestation.

Summer pruning had no effect on $N$. picticornis reduction of infestation although this treatment was repeated for two successive years. Table (2) resulted in only $10.0 \%$ reduction of the borer infestation. Summer pruning treatment did not share in the reduction of the borer infestation and should not include in the integrated control program of the pest.

Table (2) showed that applying dormant and summer pruning treatments together was of insignificant effect on the reduction of $N$. picticornis infestation $58.62 \%$.

b. Effect of mechanical treatment alone (worming):

A noticeable reduction of Killing larvae, pre-pupae and pupae stages close to the larval tunnel's openings (worming treatment) with a wire effectively reduced $N$. picticornis infestation especially when this treatment was repeated year after another. Two successive year treatment resulted in $18.26 \%$ reduction of infestation.

\section{c. Effect of microbiological treatments:}

Microbiological treatments whether with the pathogenic bacteria or fungus was relatively useless even when applied cumulatively year after another because they were highly affected with the weather factors in the field. Table (2) emphasized these results as the percentage reduction in $N$. picticornis infestation ranged reached 7.25 and $10.92 \%$ when bacteria or fungus treatments were conducted for two successive years, respectively.

\section{d. Effect of local treatments (painting and spraying):}

Local painting with "Stemex" insecticide and local spraying with Basudin $60 \%$ EC and Cidial L 50\% EC alternatively four times a year was effective in the reduction of $N$. picticornis infestation especially when was 
applied year after another. Applying these two treatments for two successive years resulted in higher percent reduction of infestation reaching 56.79 and $1.0 \%$, respectively (Table 2 ).

\section{e. Effect of combined treatments:}

Applying dormant pruning in winter with the summer pruning treatments, worming treatment, pathogenic microbiological treatments and or local chemical treatments in different combinations resulted in adequate reduction in $N$. picticornis infestation especially when carried out year after another.

Table 2: Effect of two successive year treatments on the percentage reduction in $N$. picticornis infestation in grape orchards at Nubaria district, Behaira Governorate during 2013-2014 seasons.

\begin{tabular}{|c|c|c|}
\hline Treatments & No. of holes & $\begin{array}{l}\% \text { reduction } \\
\text { of infestation }\end{array}$ \\
\hline \multicolumn{3}{|l|}{ A: Horticultural treatments: } \\
\hline Dormant pruning & 3.8 & 54.04 \\
\hline Summer pruning & 8.6 & 10.0 \\
\hline Dormant \& summer pruning & 3.3 & 58.62 \\
\hline \multicolumn{3}{|l|}{ B: Mechanical treatments: } \\
\hline Worming & 7.7 & 18.26 \\
\hline \multicolumn{3}{|l|}{ C: Microbiological Treatments: } \\
\hline Bacterial & 9.0 & 7.25 \\
\hline Fungal & 8.5 & 10.92 \\
\hline \multicolumn{3}{|l|}{ D: Local Chemical treatments: } \\
\hline Local painting & 3.5 & 56.79 \\
\hline Local spraying & 3.6 & 61.41 \\
\hline \multicolumn{3}{|l|}{ E: Combined treatments: } \\
\hline Treatments, $3+4+5$ & 2.8 & 63.21 \\
\hline Treatments, $3+4+6$ & 2.7 & 64.13 \\
\hline Treatments, $3+4+7$ & 0.9 & 81.56 \\
\hline Treatments, $3+4+8$ & 1.1 & 79.72 \\
\hline \multicolumn{3}{|l|}{ F: Untreated Treatments: } \\
\hline Check & 9.8 & -- \\
\hline
\end{tabular}

Winter and summer pruning treatments, worming treatment and pathogenic bacterial treatments showed $63.21 \%$ reduction in $N$. picticornis infestation when conducted for two successive years. Winter and summer pruning treatments, worming treatment and pathogenic fungal treatments resulted in almost similar results $64.13 \%$ reduction in the borer infestation when conducted for two successive years.

On the other hand, winter and summer pruning treatments, worming treatment together with local painting treatment with Stemex for two successive years showed almost doubled percentage reduction in the borer infestation $(81.56 \%)$.

Moreover, winter and summer pruning treatments, worming treatment together with local spraying treatment with Basudin $60 \%$ EC and Cidial L 50\% EC alternatively for two successive years resulted in almost similar 
percentage reduction in the borer infestation $(79.72 \%)$.

These combined treatments would resulted in more reduction in $N$. picticornis infestation should they applied yearly (Table, 2).

\section{Statistical analysis:}

Statistical analysis and grouping of the 13 treatments applied for one and two years concluded that there were significant differences between treatments and classified as:

\begin{tabular}{|l|l|}
\hline a. Superior group: & c. Moderate group: \\
1. Pruning, worming, and local painting for two years & 1. Local painting for one year \\
2. Pruning, worming, and local spraying for two years & 2. Dormant and summer pruning for one year \\
3. Pruning, worming, and local painting for one year & 3. Dormant pruning for one year \\
4. Pruning, worming, and local spraying for one year & 4. Local spraying for one year \\
\hline b. Sufficient group: & d. Least group: \\
1. Pruning + Worming + Fungal for two years & 1. Worming for two years \\
2. Pruning + Worming + Bacterial for two years & 2. Fungal for two years \\
3. Dormant and summer pruning for two years & 3. Summer pruning for two years \\
4. Local painting for two years & 4. Bacterial for two years \\
5. Local spraying for two years & 5. Worming for one year \\
6. Dormant pruning for two years & 6. Fungal for one year \\
7. Pruning + Worming + Fungal for one year & 7. Bacterial for one year \\
8. Pruning + Worming + Bacterial for one year & 8. Summer pruning for one year \\
\hline
\end{tabular}

\section{REFERENCES}

Abd El-latif, N. A. (1995): Studies on some insect pests of apricot trees and associated natural enemies in Fayoum Governorate. M. Sc. Thesis, Fac. of Agric., Fayoum, Cairo, Egypt, 176 pp.

Batt, A. M. (1999): Survey of the borers attacking deciduous fruit trees in Egypt with reference to certain biological and ecological studies. Egypt. J. of Agric. Res., 77 (3): 1081-1102.

Batt, M. A. (2002): Studies on some coleopterous borers infesting fruit and wood trees. M. Sc. Thesis, Fac. of Agric. Minuf. Univ. 188 pp.

Haggag, S. M. (2000): The borers attacking some wood trees with reference to some biological aspects of Niphona picticornisMul. (Coleoptera: Cerambycidae) at Minufiya Governorate. Fayoum J. of Agric. Res. \& Dev., 14 (2): 128 - 136.

Hashim, S. M. (2009): Ecological and control studies on mango tree borers and their natural enemies in Egypt. Ph.D. Thesis, Fac. of Sci., Cairo Univ., $350 \mathrm{pp}$.

Mostafa, F. F. M. (1977): Studies on the biology and ecology of the suntmacrotoma, Macrotoma palmata F. (Coleoptera: Cerambycidae). M. Sc. Thesis, Fac. of Agric., Cairo Univ., 83pp.

Snedecor, W. and A. Cochran (1990): Statistical methods. The Iwa Stat. Univ., press Ames. Iwa, U.S.A.

Willcocks, F. C. (1924): A survey of the more important economic insects and mites of Egypt with notes on life - history, habits, natural enemies and suggestion for control. Bull. Sultanic, Agric. Soc. Tech. Sec. 11. 


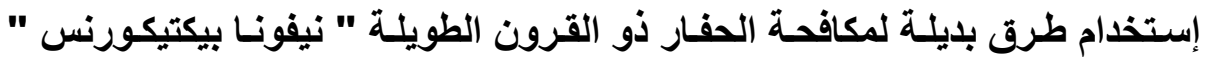

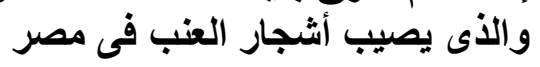

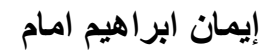

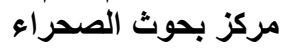

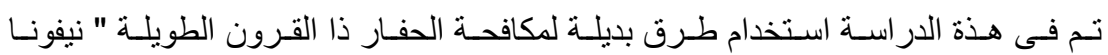

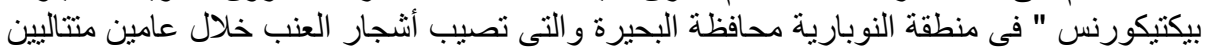

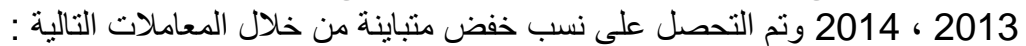
- التقليم الثتوى: كانت نسبة الخفض فى الاصـابة \% 54.04\% بعد المعاملة لعامين متتاليين

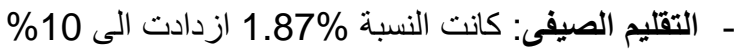

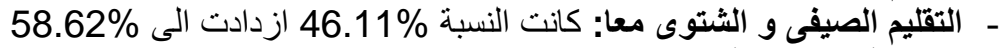

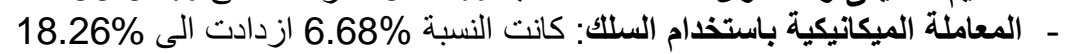
- المعاملات البكتيرية و الفطرية (Bioformulations) -

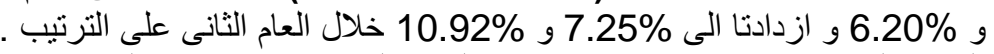

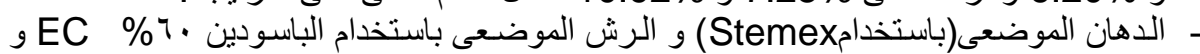

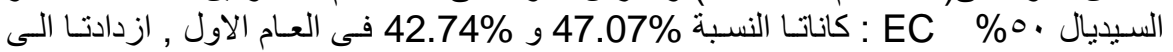

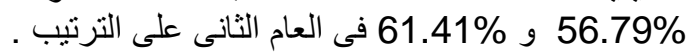

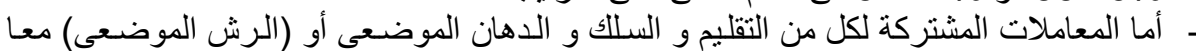

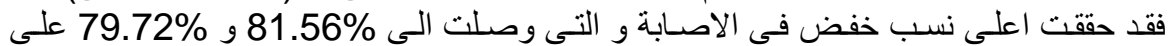

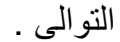

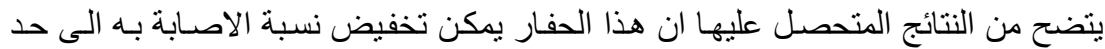

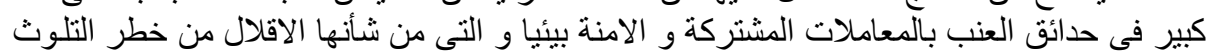

